\title{
Corrigendum: sraX: A Novel Comprehensive Resistome Analysis Tool
}

\author{
Leonardo G. Panunzi ${ }^{1,2 *}$ \\ ${ }^{1}$ Institut Pasteur, Biodiversity and Epidemiology of Bacterial Pathogens, Paris, France, ${ }^{2}$ Institut Français de Bioinformatique, \\ CNRS UMS 3601, Evry, France
}

Keywords: antimicrobial resistance, antibiotic resistance gene, resistome profiling, stand-alone software, sequence analysis, gene context visualization

\section{A Corrigendum on}

srax: A Novel Comprehensive Resistome Analysis Tool

by Panunzi, L. G. (2020). Front. Microbiol. 11:52. doi: 10.3389/fmicb.2020.00052

In the original article, there was an error in the affiliation of the corresponding author. Since a substantial part of the work was not carried out at this university, instead of "ARTbio Bioinformatics Analysis Facility, Sorbonne Université, CNRS FR3631, Institut de Biologie Paris Seine, Paris, France," the affiliation should be "Institut Pasteur, Biodiversity and Epidemiology of Bacterial Pathogens, Paris, France." Additionally, the author should also have the following affiliation: "Institut Français de Bioinformatique, CNRS UMS 3601, Evry, France." Furthermore, the Acknowledgments section should be amended to recognize supportive institutions. The correct Acknowledgments appears below.

*Correspondence: Leonardo G. Panunzi Igpanunzi@gmail.com

Specialty section This article was submitted to Antimicrobials,

a section of the journal

Frontiers in Microbiology

Received: 13 August 2020

Accepted: 17 August 2020

Published: 22 September 2020

Citation:

Panunzi LG (2020) Corrigendum: sraX: A Novel Comprehensive

Resistome Analysis Tool.

Front. Microbiol. 11:594635.

doi: 10.3389/fmicb.2020.594635

\section{ACKNOWLEDGMENTS}

The author is indebted to the Institut Français de Bioinformatique and the CONECT-AML (COllaborative NEtwork on research for Children and Teenagers with Acute Myeloid Leukemia) consortium for their support. In addition, the author acknowledges Mr. Mario R. Panunzi and MS. Brenda N. Henriquez for their invaluable help and inspiration, and specially dedicates this paper to them.

The author apologizes for these errors and states that these do not affect the scientific conclusions of the article in any way. The original article has been updated.

Copyright (c) 2020 Panunzi. This is an open-access article distributed under the terms of the Creative Commons Attribution License (CC BY). The use, distribution or reproduction in other forums is permitted, provided the original author(s) and the copyright owner(s) are credited and that the original publication in this journal is cited, in accordance with accepted academic practice. No use, distribution or reproduction is permitted which does not comply with these terms. 